\title{
Aspek Hukum Lembaga Pinjaman Online Ilegal Di Indonesia
}

\author{
Dhevi Nayasari Sastradinata \\ dhevinss@yahoo.com
}

Fakultas Hukum Universitas Islam Lamongan

\begin{abstract}
ABSTRA K
Terdapat aturan lain bagi perusahaan fintech yang terbukti melakukan pelanggaran hukum. Misalnya, dia menjelaskan bagi perusahaan fintech yang melakukan pelanggaran berupa penyeberan data pribadi dapat dikenakan Pasal 32 juncto (jo) Pasal 48 UU No. 11 Tahun 2008 Juncto UU No. 19 Tahun 2016 tentang Informasi dan Transaksi Elektronik (ITE). Kemudian, pengancaman perusahaan fintech terhadap nasabah dapat dijerat dengan Pasal 368 Kitab Undang-Undang Hukum Pidana (KUHP) dan Pasal 29 jo Pasal 45B UU ITE. PPerusahaan fintech "nakal" tersebut juga dapat dijerat Pasal 55 KUHP karena terlibat dalam tindakan pidana. Apabila, tindak pidana tersebut sampai berbentuk kekerasan fisik, pengambilan barang maka dapat dikenakan sanksi sesuai dengan KUHP Pasal 170, Pasal 351, Pasal 368 Ayat 1, Pasal 335 Ayat 1 pasca-putusan Mahkamah Konstitusi.
\end{abstract}

Kata Kunci ; Perbankan, Finetech, Aspek Hukum

\section{PENDAHULUAN}

Indonesia merupakan negara berkembnag dengan dengan jumalah penduduk nomor-4 terbanyak di Dunia yang saat ini sedang memulai pembangunan infrastruktur untuk persiapan menghadapi Revolusi Industri 4.0.di era ini kegiatan ekonomi akan banyak dilakukan dengan cara digital atau berbasis internet. Kehadiran ekonomi digital akan membawa iklim baru dalam dunia ekonomi dalam kegiatan industry yang ada di Indonesia dan yang saat ini sudah banyak di rasakan oleh masyrakat khususnya generasi milenial, hal ini didorong oleh kemajuan teknologi yang kian hari bertambah maju.

Diawali dengan kemudahan di zaman sekarang, karena adanya kebebasan di internet kebanyakan kebutuhan manusia setiap hari makin mudah akibat adanya internet, tanpa harus keluar rumah seseorang sudah bisa melakukan transaksi elektronik seperti transaksi keuangan secara online. Adanya kemudahan tersebut mendorong banyak pihak untuk membuat jasa pinjaman uang atau 
modal dana menggunakan internet (Online) atau biasa disebut Financial Technology (Fintech). Pinjaman online hadir sebagai solusi bagi masyarakat yang membutuhkan pinjaman uang dengan cepat tanpa harus melalui proses panjang seperti di bank konvensional.

Pesatnya perkembangan teknologi ikut membawa perubahan terhadap gaya hidup masyarakat yang kini bermacam-macam sesuatu dapat dilakukan secara cepat dan mudah menggunakan layanan berbasis online atau menggunakan jaringan internet, baik dalam melakukan transaksi belanja, memesan hotel, tiket pesawat, atau melakukan transaksi peminjaman uang secara online, yang saat ini kehadirannya sedang popular di tengah masyarakat karena didukung dengan banyaknya bermunculan starup atau perusahaan rintisan yang menawarkan beragam layanan digital seperti pembayaran dan peminjaman uang. Hadirnya layanan jasa keuangan berbasis teknologi ini memiliki istilah yakni

\footnotetext{
${ }^{1}$ Kiko Sarwin,Dkk, Eds. Kajian Perlindungan Konsumen Sektor Jasa Keuangan:Perlindungan Konsumen Pada
}

Financial Technology atau di singkat dengan Fintech.

Financial Technology yaitu jika diartikan kedalam bahasa Indonesia yaitu teknologi keuangan. Secara sederhana, Fintech memiliki arti sebagai pemanfaatan dari perkembangan teknologi informasi untuk meningkatkan layanan industry dibidang keuangan. Definisi lainnya adalah variasi model bisnis dan perkembangan teknologi yang memiliki potensi untuk meningkatkan industri layanan keuangan. ${ }^{1}$

Fintech merupakan penerapan dari peningkatan layanan dalam bidang jasa perbankan dan keuangan yang umumnya dilakukan oleh rintisan perusahaan (startup) dengan pemanfaatn teknologi software, internet, komunikasi dan komputasi terkini. Konsep ini mengadaptasi perkembangan teknologi yang dipadukan dengan bidang finansial sehingga bisa menghadirkan proses transaksi keuangan yang lebih praktis, aman serta moderen. ${ }^{2}$

Fintech (Jakarta: Departemen Perlindungan Konsumen OJK, 2017) H8.

${ }^{2}$ Nofie Iman, Financial Technology dan Lembaga Keuangan Keuangan ( Yogyakarta : 
Semakin berkembangnya teknologi, jenis-jenis Fintech semakin beragam, diantaranya seperti inovasi teknologi finansial terkait pembayaran dan transfer, lembaga jasa keuangan, dan perusahaan startup Fintech yang menggunakan teknologi baru untuk memberikan layanan yang lebih cepat, murah dan nyaman. Menurut bank Indonesia jenis Fntech yang paling diminati yakni Peer to Peer (P2P) Lending karena banyak keuntungan bagi penyedia jasa keungan, yaitu:

1. Sudah terdaftar dalam OJK

2. Memberikan pinjaman dengan cepat dan mudah

\section{Mendiversifikasi investasi}

\section{Bunga yang tinggip}

Kehadiran fintech merupakan soslusi bagi masyarakat yang belum tersentuh oleh layanan jasa perbankan sehingga menjadi solusi alternatif untuk mendatangkan kemudahan bagi masyarakat untuk mendapatkan layanan transaksi keuangan yang mudah dan cepat.
Sejak Otoritas Jasa Keuangan OJK membuat aturan mengenai Pear to Pear lending melalui peraturan Nomor 77/POJK.01/2016. Industri fintech mengalami perkembangan sangat pesat dan membawa masyarakat untuk minum madu atau racun. Perkembangan teknologi dan kemudahan yang diberikan menjadi alasan banyak masyarakat menggunakan jasa perusahaan start up keuangan. Namun, seiring perkembangan tersebut, isu-isu negatif mulai banyak bermunculan dan mengancam keberadaan industri digital tersebut. Terkesan, industri fintech menjebloskan masyarakat minum racun. Mulai dari fenomena bunga supertinggi, sistem penagihan yang menerapkan bentuk teror, penipuan hingga pencurian dan penggunaan data nasabah, sampai beroperasinya fintech ilegal. Yang paling parah adalah penagihan bentuk teror denganmenggunakan debt collector. Fakta yang tidak bisa disembunyikan dari fenomena masyarakat kecil bahkan generasi milenial yang terbelit utang pada 
"rentenir digital" adalah gaya hidup sebagian orang Indonesia yang masih sangat konsumtif dan impulsif. Penyelesaian jalan pintas adalah meminjam lewat "rentenir online" yang pada zaman digital ini serba cepat dan serba mudah. Padahal perilaku rentenir digital sama dengan rentenir konvensional yang cenderung melihat nasabah. Rentenir digital menjadi jalan cepat nasabah terlilit utang. Dalam konteks dunia digital, perilaku masyarakat dengan mental lama seperti itu bisa dilihat sebagai ketidaksiapan kita memasuki era Revolusi $4.0 .^{3}$

$$
\text { Pinjaman atau kredit }
$$

berdasarkan pasal 1 ayat (11)

Undang-undang Perbankan RI NO.

10 Tahun 1998 sebagai berikut:

"kredit adalah penyediaan uang atau tagihan tagihan yang dipersamakan dengan itu, berdasarkan persetujuan atau kesepakatan pinjam-meminjam antara bank dengan pihak lain yang mewajibkan pihak peminjam melunasi utangnya setelah jangka waktu tertentu dengan pemberian bunga”. Debitur adalah pihak yang berhutang ke pihak lain biasanya dengan menerima sesuatu dari kreditur yang dijanjikan debitur untuk dibayar kembali pada masa yang akan datang. Pemberi pinjaman akan memerlukan juga jaminan atau agunan dari pihak debitur. Jika seorang debitur gagal membayar pada tenggat waktu yang dijanjikan, suatu proses koleksi formal dapat dilakukan yang kadang mengizinkan penyitaan harta milik debitur untuk memaksa pembayaran. .

Online adalah bersal dari kata on dan line, on artinya hidup, line artinya saluran. Pengertian online adalah keadaan komputer atau smartphone yang terkoneksi dengan jaringan internet. Arti dari online adalah sebuah istilah yang digunakan untuk menyebutkan ketika kita sedang terhubung dengan jaringan internet. Sehingga apabila komputer atau smartphone kita online maka kita dapat mengakses internet, mencari informasi, melakukan transaksi

\footnotetext{
${ }^{3}$ https://news.detik.com/kolom/d4437992/pinjaman-online-madu-atauracun. Diskses pada 25 Desember 2019
} 
digital ataupun melakukan transaksi pinjam-meminjam uang.

Pinjaman online adalah fasilitas pinjaman uang oleh penyedia jasa keuangan yang berbasis teknologi yang beroperasi secara online. Hadirnya fintech khususnya model bisnis layanan pinjam meminjam uang berbasis teknologi informasi dengan system (Peer to Peer Lending) yaitu penyelengaraan perjanjian pinjam-meminjam yang mempertemukan kreditur dan debitur melalui jaringan internet, yang dapat memangkas proses panjang dalam mengajukan peminjaman uang. Dalam pinjaman online ini, pelaksanaan pemberian kredit dapat dilaksanakan dengan cepat. Selain itu, pemberian pinjaman dapat diberikan tanpa Agunan, lain halnya dengan bank yang secara yuridis meyatakan bahwa kredit tanpa angunan (KTA) tidak mungkin terjadi, dan walaupun bank memberikan kredit tanpa agunan khusus, hal itu bukan berati bahwa pemberian kredit tersebut tanpa disertai agunan sama sekali. ${ }^{4}$
Dulu, sebelum ada fintech, seseorang atau biasa disebut debitur jika butuh dana maka harus datang ke bank untuk melakukan transaksi dan mengisi formulir peminjaman dan menyerahkan berkas-berkas yang menjadi syarat untuk melakukan transaksi pinjaman, lalu bank harus melakukan survei terhadap debitur, kemudian melakukan analisis kelayakan, jika semua lancar baru bank bisa mencairkan pinjaman yang di ajukan oleh debitur. Proses yang cukup rumit itu yang mendorong seseorang enggan melakukan transaksi pinjaman uang melalui bank dan lebih memilih peminjaman secara online.

\section{METODE PENELITIAN}

Tipe penelitian hukum yang dilakukan adalah yuridis normatif (hukum normatif). Metode penelitian hukum normatif adalah suatu prosedur penelitian ilmiah untuk menemukan kebenaran berdasarkan logika keilmuan hukum dari sisi

\footnotetext{
${ }^{4}$ Djoni S. Gozali dan Rachmadi Usman, Hukum Perbankan, cet. II, Sinar Grafika, Jakarta, 2012, h. 286
} 
normatifnya. ${ }^{5}$ Oleh karena itu penelitian hukum ini difokuskan untuk mengkaji penelitian hukum tentang kaidah-kaidah atau normanorma dalam hukum positif, yakni norma hukum yang terkait dengan rumusan masalah

\section{PEMBAHASAN}

Permasalahan pinjaman online atau financial technology peer to peer lending (fintech $P 2 P$ ) kian hari terus menjadi sorotan publik. Terakhir, permasalahan fintech ini bahkan merenggut nyawa nasabah yang memilih bunuh diri akibat depresi karena penagihan pinjaman tersebut. Sayangnya, penyelesaian hukum permasalahan ini masih minim sehingga kasus-kasus serupa terus bermunculan.

Bentuk pelanggaran perusahaan fintech ini juga beragam jenisnya. Mulai penagihan intimidatif, penyebaran data pribadi hingga pelecehan seksual diduga terjadi dalam persoalan ini. Ragam dugaan pelanggaran tersebut salah satunya

${ }^{5}$ Johnny Ibrahim, Teori \& Metode Penelitian Hukum Normatif, Banyumedia Publishing, Malang 2006, h..57 bersumber dari hasil laporan pengaduan masyarakat yang diterima Lembaga Bantuan Hukum (LBH) Jakarta sejak tahun lalu. ${ }^{6}$ Terdapat aturan lain bagi perusahaan fintech yang terbukti melakukan pelanggaran hukum. Misalnya, dia menjelaskan bagi perusahaan fintech yang melakukan pelanggaran berupa penyeberan data pribadi dapat dikenakan Pasal 32 juncto (jo) Pasal 48 UU No. 11 Tahun 2008 Juncto UU No. 19 Tahun 2016 tentang Informasi dan Transaksi Elektronik (ITE). Kemudian, pengancaman perusahaan fintech terhadap nasabah dapat dijerat dengan Pasal 368 Kitab UndangUndang Hukum Pidana (KUHP) dan Pasal 29 jo Pasal 45B UU ITE. erusahaan fintech "nakal" tersebut juga dapat dijerat Pasal 55 KUHP karena terlibat dalam tindakan pidana. Apabila, tindak pidana tersebut sampai berbentuk kekerasan fisik, pengambilan barang maka dapat dikenakan sanksi sesuai dengan KUHP Pasal 170, Pasal 351, Pasal

6

https://www.hukumonline.com/berita/baca llt5c6cacf0c858c/pasal-pasal-pidana-yangbisa-jerat-perusahaan-fintech-ilegal/ 
368 Ayat 1, Pasal 335 Ayat 1 pascaputusan Mahkamah Konstitusi.

BI yang secara khusus menerbitkan berbagai peraturan soal penyelenggaraan fintech. Berikut pengaturan fintech di Indonesia

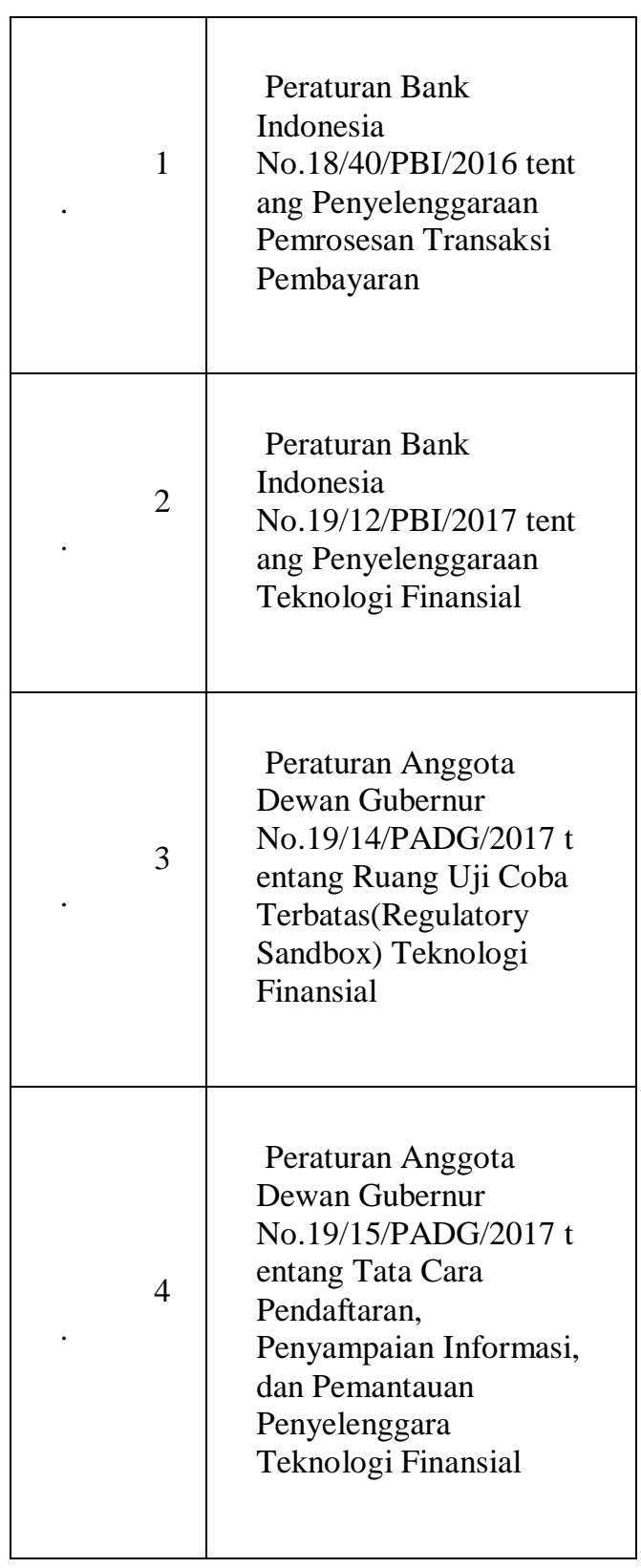

Dalam Peraturan Bank Indonesia No.19/12/PBI/2017 tentang Penyelenggaraan Teknologi Finansial (PBI Tekfin) telah ditegaskan definisi yang digunakan oleh BI mengenai fintech hingga kategori dan kriterianya.

Aturan mengenai layanan pinjam uang berbasis aplikasi atau elektronik yang terdapat dalam Peraturan Otoritas Jasa Keuangan Nomor 77/POJK.01/2016 Tahun 2016 tentang Layanan Pinjam Meminjam Uang Berbasis Teknologi Informasi ("POJK 77/2016"). Layanan Pinjam Meminjam Uang Berbasis Teknologi Informasi adalah penyelenggaraan layanan jasa keuangan untuk mempertemukan pemberi pinjaman dengan penerima pinjaman dalam rangka melakukan perjanjian pinjam meminjam dalam mata uang rupiah secara langsung melalui sistem elektronik dengan menggunakan jaringan internet. Menurut Pasal 3 ayat (1) huruf e Peraturan Bank Indonesia Nomor 19/12/PBI/2017 Tahun 2017 tentang Penyelenggaraan Teknologi Finansial ("POJK 19/2017”) bahwa layanan pinjam uang berbasis aplikasi 
atau teknologi informasi merupakan salah satu jenis Penyelenggaraan Teknologi Finansial (Fintech) kategori Jasa Keuangan/Finansial Lainnya, hadirnya fintech khususnya model bisnis layanan pinjam meminjam uang berbasis teknologi informasi (Peer to Peer Lending), dapat memangkas proses panjang dalam mengajukan kredit. Ketua Dewan Komisioner OJK, Wimboh Santoso mengatakan bahwa hadirnya fintech yang berkembang cepat/pesat memerlukan kebijakan yang cepat dan tepat dari regulator. Setelah melihat pesatnya penyelenggara Peer to Peer Lending,Pemberi Pinjaman adalah orang, badan hukum, dan/atau badan usaha yang mempunyai piutang karena perjanjian Layanan Pinjam Meminjam Uang Berbasis Teknologi Informasi. Penerima Pinjaman adalah orang dan/atau badan hukum yang mempunyai utang karena perjanjian Layanan Pinjam Meminjam Uang Berbasis Teknologi Informasi. Perjanjian pelaksanaan Layanan Pinjam Meminjam Uang Berbasis Teknologi Informasi meliputi:
1) perjanjian antara Penyelenggara dengan Pemberi Pinjaman; dan

2) perjanjian antara Pemberi Pinjaman dengan Penerima Pinjaman.

Penyelenggara dapat bekerja sama dengan penyelenggara layanan jasa keuangan berbasis teknologi informasi sesuai dengan ketentuan peraturan perundangundangan. Kemudian perlu diingat bahwa, dalam melakukan usahanya, penyelenggara wajib mengajukan pendaftaran dan perizinan kepada Otoritas Jasa Keuangan ("OJK"), terkait batasan jumlah uang yang bisa dipinjam melalui penyelenggara Layanan Pinjam Meminjam Uang Berbasis Teknologi Informasi, Pasal 6 POJK 77/2016 mengatur sebagai berikut:

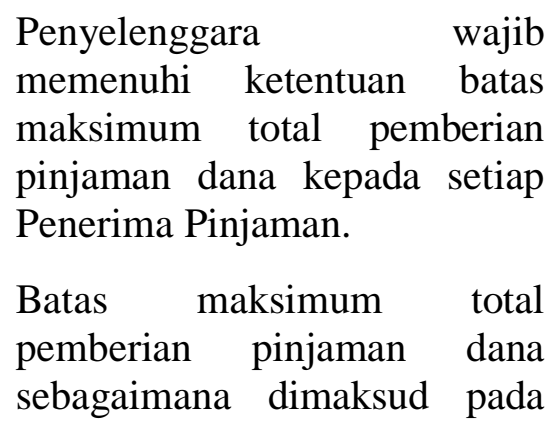


ayat (1) ditetapkan sebesar Rp 2.000.000.000,00 (dua miliar rupiah).

OJK dapat melakukan peninjauan kembali atas batas maksimum total pemberian pinjaman dana sebagaimana dimaksud pada ayat (2).

Berdasarkan ketentuan diatas ada batasan jumlah pinjaman yang ditetapkan OJK dalam penyelenggaraan layanan pinjaman berbasis aplikasi, yaitu maksimum Rp 2 miliar.

\section{KESIMPULAN}

Terdapat aturan lain bagi perusahaan fintech yang terbukti melakukan pelanggaran hukum. Misalnya, dia menjelaskan bagi perusahaan fintech yang melakukan pelanggaran berupa penyeberan data pribadi dapat dikenakan Pasal 32 juncto (jo) Pasal 48 UU No. 11 Tahun 2008 Juncto UU No. 19 Tahun 2016 tentang Informasi dan Transaksi Elektronik (ITE). Kemudian, pengancaman perusahaan fintech terhadap nasabah dapat dijerat dengan Pasal 368 Kitab Undang-Undang Hukum Pidana (KUHP) dan Pasal 29 jo Pasal 45B UU ITE. erusahaan fintech "nakal" tersebut juga dapat dijerat Pasal 55 KUHP karena terlibat dalam tindakan pidana. Apabila, tindak pidana tersebut sampai berbentuk kekerasan fisik, pengambilan barang maka dapat dikenakan sanksi sesuai dengan KUHP Pasal 170, Pasal 351, Pasal 368 Ayat 1, Pasal 335 Ayat 1 pascaputusan Mahkamah Konstitusi.

\section{REFERENSI}

Djoni S. Gozali dan Rachmadi Usman, Hukum Perbankan, cet. II, (Sinar Grafika, Jakarta 2012)

Kiko Sarwin,Dkk, Eds. Kajian Perlindungan Konsumen Sektor Jasa Keuangan:Perlindungan Konsumen Pada Fintech (Departemen Perlindungan Konsumen OJK, Jakarta 2017)

Johnny Ibrahim, Teori \& Metode Penelitian Hukum Normatif. (Bannyumedia Publishing, Malang 2006)

Nofie Iman, Financial Technology dan Lembaga Keuangan Keuangan (Gathering Mitra Linkage Bank Syariah Mandiri, Yogyakarta 2016)

Peter Mahmud Marzuki. Penelitian Hukum Edisi Revisi. (Kencana Prenada Media Group. Jakarta. 2013

Kitab Undang-Undang Hukum Pidana Kitab Undang-Undang Hukum Acara Pidana,

Undang-Undang Perbankan Nomor 10 Tahun 1998 Tentang Perbankan Peraturan Otoritas Jasa Keuangan Nomor 07 Tahun 2013 Tentang Perlindungan Konsumen 